\title{
Polymyositis and dermatomyositis: no persistence of enterovirus or encephalomyocarditis virus RNA in muscle
}

\author{
Peter J H Jongen, Gerrit J Zoll, Marielle Beaumont, Willem J G Melchers,
} Levinus B A van de Putte, Jochem M D Galama

\begin{abstract}
Objectives-A persistent infection of enteroviruses and cardioviruses has been implicated in polymyositis and dermatomyositis, but conventional hybridisation studies of the presence of enterovirus RNA and encaphalomyocarditis (EMC) virus RNA in affected muscle have yielded conflicting results. To investigate further the possibility of viral persistence, the presence of viral RNA in muscle from patients with adult onset polymyositis and dermatomyositis was investigated using a polymerase chain reaction (PCR) technique.
\end{abstract}

Methods-Muscle tissue was obtained from 10 patients with polymyositis and five patients with dermatomyositis, all with adult onset active disease. A PCR was performed using primers with high specificity for enterovirus and EMC virus RNA, followed by Southern blot hybridisation with an oligonucleotide probe directed against the internal portion of the amplified product. A PCR directed against the Abelson tyrosine kinase mRNA served as an internal control for the presence and quality of RNA.

Results-A specific amplification for enterovirus or for EMC virus could not be seen in any of the muscle biopsy samples, despite a sensitivity of about 30 plaque forming units for enterovirus and of $\mathbf{1 0 0}$ plaque forming units for EMC virus. Southern blot hybridisation confirmed these results in that positive controls hybridised with the oligonucleotide probe, but no signal was obtained with the muscle specimens.

Conclusion-A sensitive and specific PCR technique showed no evidence of the presence of enterovirus or EMC virus RNA in muscle samples from patients with polymyositis or dermatomyositis. These data do not support the proposal that viral RNA persistence plays a part in these idiopathic inflammatory myopathies.

(Ann Rheum Dis 1993; 52: 575-578)

Polymyositis and dermatomyositis are specific diagnoses in the group of inflammatory myopathies. $^{12}$ In these two disorders an autoimmune origin is supported by the presence of various autoantibodies, the evidence of myotoxicity mediated by cytotoxic $\mathrm{T}$ cells or complement mediated microangiopathy, their response to immunotherapies, and their association with diseases of which the autoimmune character has been established more firmly..$^{1-3}$ The agents initiating self sensitisation and the specific antigens against which the immune reactions are directed are unknown, however. ${ }^{1}$

Viruses can induce autoimmunity in mice m $^{4-6}$ and, probably, in humans. ${ }^{47}$ Electron microscopic $^{8}$ and serological ${ }^{910}$ studies have implicated the enterovirus and cardiovirus subgroup of picornaviruses in polymyositis and dermatomyositis, but reports of the isolation of the viruses from muscle tissue are rare. ${ }^{1}$ Dot spot hybridisation studies of the presence of enterovirus specific RNA in affected muscle have yielded conflicting results. Bowles et al found coxsackievirus B specific RNA in muscle tissues from patients with polymyositis or dermatomyositis, ${ }^{11}$ whereas Bunn and Walport could not detect this virus in patients with polymyositis. ${ }^{12}$ Unconfirmed in situ hybridisation studies in patients with polymyositis and dermatomyositis have found enterovirus specific $^{13}$ or encephalomyocarditis (EMC) virus specific RNA. ${ }^{14}$

Persistent infection of enterovirus and EMC virus as a pathogenic factor in polymyositis and dermatomyositis is therefore a subject of controversy. To investigate further the possibility of viral RNA persistence in polymyositis and dermatomyositis, we extracted RNA from muscle biopsy samples from patients with active disease, and used a highly specific and sensitive polymerase chain reaction (PCR) technique for the detection of enterovirus and EMC virus RNA.

\section{Patients and methods}

PATIENTS

We studied 10 patients with adult onset polymyositis and five patients with adult onset dermatomyositis attending the centre for neuromuscular diseases of the University of Nijmegen. All patients fulfilled the diagnostic criteria for definite polymyositis or definite dermatomyositis, as formulated by Dalakas. ${ }^{1}$ Of the patients with polymyositis five were men and five were women; their ages ranged from 34 to 73 years. The patients with 
Diagnosis, age, sex, duration of symptoms, and associated diseases of the patients with polymyositis (PM) and dermatomyositis (DM)

\begin{tabular}{|c|c|c|c|c|c|}
\hline $\begin{array}{l}\text { Patient } \\
\text { No }\end{array}$ & Diagnosis & $\begin{array}{l}\text { Age } \\
\text { (years)* }\end{array}$ & Sex & $\begin{array}{l}\text { Disease } \\
\text { duration }\end{array}$ & Associated disease \\
\hline 1 & PM & 66 & F & Four years & - \\
\hline 2 & PM & 70 & $\mathrm{~F}$ & One month & Primary biliary cirrhosis \\
\hline 3 & PM & 59 & M & Six weeks & \\
\hline 4 & PM & 73 & M & 16 years & Dilated cardiomyopathy \\
\hline 5 & PM & 63 & $\mathbf{M}$ & Three months & \\
\hline 6 & PM & 51 & M & One year & Adenocarcinoma (site unknown) \\
\hline 7 & PM & 73 & $\mathbf{F}$ & 2.5 months & 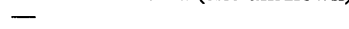 \\
\hline 8 & PM & 59 & $\mathrm{~F}$ & 13 years & - \\
\hline 9 & PM & 34 & $\mathbf{M}$ & 34 years & - \\
\hline 10 & PM & 58 & $\mathrm{~F}$ & Nine years & - \\
\hline 11 & $\mathrm{DM}$ & 63 & $\mathrm{~F}$ & One month & Interstitial lung fibrosis \\
\hline 12 & $\mathrm{DM}$ & 24 & $\mathrm{~F}$ & Three months & - \\
\hline 13 & $\mathrm{DM}$ & 34 & $\mathrm{~F}$ & Eight years & - \\
\hline 14 & $\mathrm{DM}$ & 42 & $\mathrm{~F}$ & Five years & - \\
\hline 15 & $\mathrm{DM}$ & 22 & $\mathrm{~F}$ & Seven years & - \\
\hline
\end{tabular}

^At time of muscle biopsy. conserved 5 'NCR of enterovirus and have been shown to detect 60 of the 66 different enterovirus types tested. ${ }^{16}$

For amplification of EMC RNA we used an antisense primer (5'CACGTGGCTTTTGGCCGCAGAGG3') and a sense primer (5'CGAAGCCGCTTGGAATA3') specific for cardioviruses and Theiler's murine encephalomyocarditis virus (TMEV) (Zoll G J, Galama J M D, Melcher W J G, unpublished data). For Southern blot analysis we used an EMC/TMEV specific oligonucleotide probe (5'CGTGTTACCAGGTGGGG3'). A fragment of 282 base pairs is obtained with positive specimens.

As an internal control for the presence and quality of RNA, we performed a PCR directed against the Abelson tyrosine kinase mRNA, which is expressed in muscles. ${ }^{17}$ A positive PCR results in a fragment of 218 base pairs. ranged from 22 to 63 years. The table gives the diagnosis, age, sex, duration of symptoms at time of examination, and associated diseases of the patients. Biopsy samples were obtained from a quadriceps muscle for diagnostic reasons. At the time of examination all patients had progressive muscle weakness and increased serum creatine kinase concentrations. For RNA extraction and viral RNA detection, tissue samples of approximately 25-30 $\mathrm{mm}^{2}$ were immediately frozen in liquid nitrogen and stored at $-80^{\circ} \mathrm{C}$ until use. Fifteen patients with non-inflammatory non-immune mediated neuromuscular disorders were studied as controls.

SAMPLE PROCESSING

RNA from muscle samples was purified using a single extraction with guanidiniumthiocyanate-phenol-chloroform according to the method of Chomczynski and Sacchi. ${ }^{15}$ RNA was dissolved in $50 \mu$ l distilled water treated with diethylpyrocarbonate. To all samples, human placenta RNAse inhibitor (RNasin; Promega) was added to a concentration of $0.4 \mathrm{U} / \mu \mathrm{l}$. The samples were stored at $-80^{\circ} \mathrm{C}$. The reverse transcriptase PCR and the determination of the amplified products were performed as described previously. ${ }^{16}$ In brief, for enteroviral RNA amplification, the RNA was transcribed in cDNA using reverse transcriptase and an antisense primer (3'ATTGTCACCATAAGCAGCCA5'). After completing the reverse transcriptase reaction, the buffer conditions were adapted for the PCR, and the sense primer (5'TCCTCCGGCCCCTGAATGCG3') was added. RNA/cDNA hybrids were denaturated at $94^{\circ} \mathrm{C}$ for five minutes. The thermal profile included 40 cycles of denaturation at $94^{\circ} \mathrm{C}$ for one minute, primer annealing at $42^{\circ} \mathrm{C}$ for one minute, and primer extension at $72^{\circ} \mathrm{C}$ for two minutes. The reactions were analysed by electrophoresis on a $2 \%$ agarose gel stained with ethidium bromide, and by Southern blot analysis using an endlabelled oligonucleotide probe (5'AAACACGGACACCCAAAGTA3'). A positive PCR generates a fragment of 155 base pairs. The primers were selected in the

\section{Results}

When a titrated stock of virus was serially diluted and added to negative muscle samples before RNA extraction, we obtained a sensitivity of approximately 30 plaque forming units for enterovirus (fig 1A) and of 100 plaque forming units for EMC (fig 1B). A specific amplification for enterovirus (fig $2 \mathrm{~A}$ ) or for EMC virus (fig 2B) was not observed in any of the muscle biopsy samples. A specific amplification product of 155 base pairs was seen from enterovirus RNA and from enterovirus CDNA, and of 282 base pairs from EMC virus RNA, which were used as positive controls. In all samples the reverse transcriptase PCR on the non-relevant mRNA of the Abelson tyrosine kinase gene resulted in a specific amplification product of 218 base pairs, confirming the presence of adequate RNA in the tissues. Southern blot hybridisation with an oligonucleotide probe directed against the internal portion of the amplified product confirmed the results as observed directly on gel electrophoresis: the positive controls hybridised with the oligonucleotide probe, but no signal was obtained with the muscle specimens.

\section{Discussion}

The aetiology of polymyositis and dermatomyositis is unknown, but evidence is accumulating that viruses belonging to the enterovirus and cardiovirus subgroup of picornaviruses play a part. ${ }^{8-11} 1314$ Immunopathogenic studies in experimental murine myositis support the idea of viral persistence: in coxsackievirus $B$ induced myositis ${ }^{18}$ and in EMC virus induced myositis, ${ }^{19}$ hybridisation studies showed viral RNA in affected muscle, at times when cultures for the virus were negative. In various human disorders viral persistence has been established. Conventional hybridisation $^{20} 21$ as well as PCR studies ${ }^{22}$ detected coxsackievirus $B$ RNA in endomyocardial biopsy samples from patients with dilated cardiomyopathy and myocarditis. Muscle from patients with chronic fatigue 
$\begin{array}{lllllllllllllllll}M & 1 & 2 & 3 & 4 & 5 & 6 & 7 & 8 & 9 & 10 & 11 & 12 & 13 & - & -\end{array}$

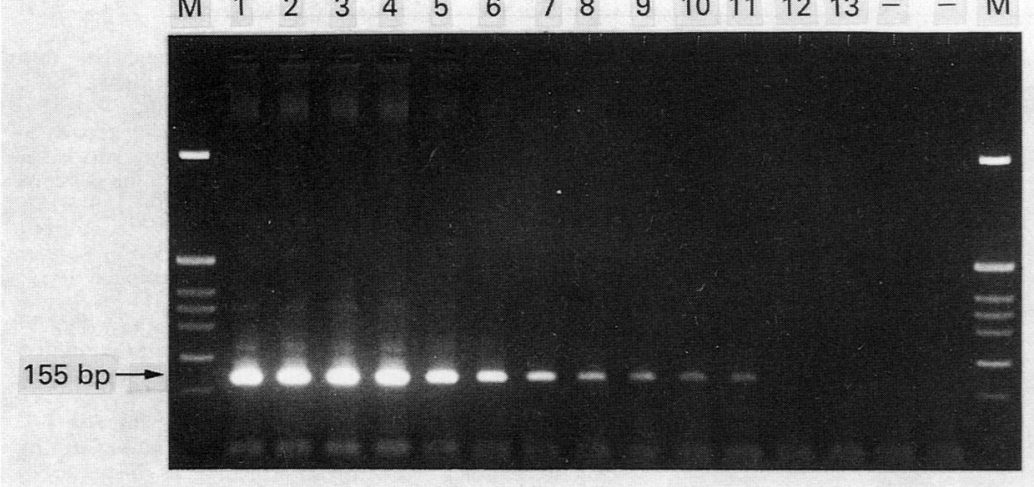

B

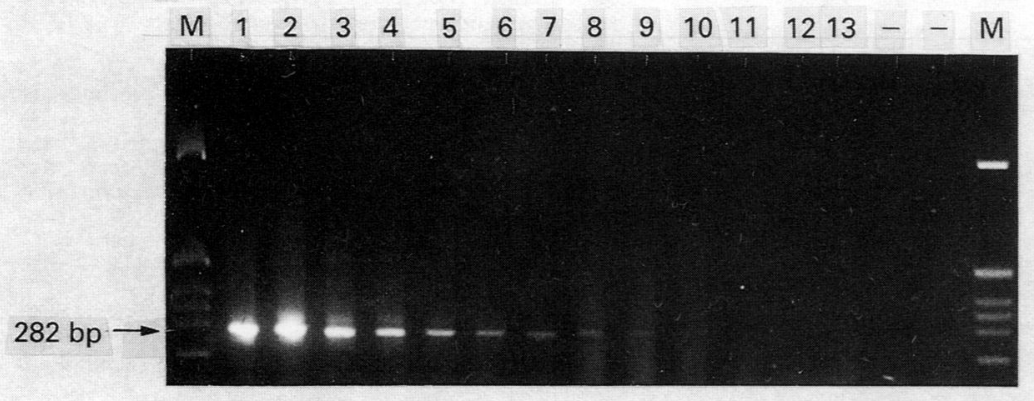

Figure 1 (A) Sensitivity of the enterovirus polymerase chain reaction. Lane 1,106.5 plaque forming units (pfu); lane 2, $10^{6.0}$ pfu; lane 3, $10^{5.5}$ pfu; lane 4, $10^{5.0}$ pfu; lane 5, $10^{4.5} \mathrm{pfu}$; lane 6, $10^{4.0} \mathrm{pfu}$; lane $7,10^{3.5} \mathrm{pfu}$; lane 8, $10^{3.0} \mathrm{pfu}$; lane 9, $10^{2.5} \mathrm{pfu}$; lane 10 , $10^{2.0} \mathrm{pfu}$; lane 11, $10^{1.5} \mathrm{pfu}$; lane $12,10^{1.0} \mathrm{pfu}$; lane $13,10^{0.5} \mathrm{pfu}$. Lane -, negative control (distilled water). Lane M, length marker ( $p B R 322 \times$ HinfI). (B) Sensitivity of the encephalomyocarditis virus polymerase chain reaction. Lane $1,10^{6.5} \mathrm{pfu}$; lane $2,10^{6.0} \mathrm{pfu}$; lane 3, $10^{5.5} \mathrm{pfu}$; lane 4, $10^{5.0} \mathrm{pfu}$; lane 5, $10^{4.5} \mathrm{pfu}$; lane 6, $10^{4.0} \mathrm{pfu}$; lane $7,10^{3.5} \mathrm{pfu}$;

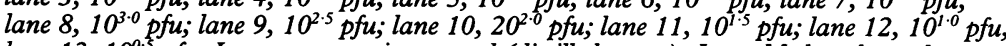
lane $13,10^{0.5}$ pfu. Lane -, negative control (distilled water). Lane M, length marker (pBR322 $\times$ HinfI).
The discrepancies between these reports, including ours, may result from the different methods used, or from differences between patient groups. Although the sensitivity of the RNA PCR may be limited by the efficiency of RNA extraction and reverse transcription, the PCR technique has been described as superior to conventional hybridisation techniques for the detection of enteroviral RNA (Zoll G J, Galama J M D, Melchers W J G, unpublished data). ${ }^{17}$ In our study the positive Abelson band confirmed the quality of the RNA samples for PCR. As all muscle cells express the Abelson gene, however, it cannot be excluded that negative viral results could be obtained from Abelson positive samples if the virus was present in only a few cells.

We obtained a sensitivity of 30 plaque forming units for enterovirus and of 100 plaque forming units for EMC virus, which is within the range of values reported elsewhere. ${ }^{24} 25 \mathrm{It}$ should be remembered, however, that virus preparations may contain an excess of noninfectious to infectious particles and thus small amounts of virus may not be detected in spite of an apparently high sensitivity. On the other hand, pathogenic changes, which are clinically relevant, are not likely to result from minute amounts of viral RNA. Moreover, our previous finding of enterovirus RNA in a cardiac muscle biopsy sample from a patient with dilated cardiomyopathy and in muscle from mice with coxsackievirus B induced myositis indicates an adequate sensitivity of the PCR for the detection of persistent viral RNA. ${ }^{16}$

Our approach does not preclude the possibility that we have missed enterovirus and EMC virus RNA sequences not detectable by the primers used. As viral RNA without the highly conserved 5 NCR is incapable of translation and replication, however, a persistent infection with such RNA sequences is not likely to occur. Likewise, picornaviruses not belonging to the enterovirus or cardiovirus subgroup could have been missed with our primers owing to their type specificity. There is little evidence, however, that other picornavirus subgroups are involved in polymyositis or dermatomyositis.

As has been reported elsewhere, ${ }^{24}$ most studies of viral persistence in myositis have been of children. In view of the differences between adult and childhood dermatomyositis, ${ }^{1}$ it cannot be excluded that in childhood myositis viral RNA does persist. For comparison, coxsackievirus B1 induces chronic myositis in mice only if inoculated within 48 hours of birth. ${ }^{26}$ It is possible that immature immune systems do not completely clear the enterovirus, and thus predispose to the development of dermatomyositis or polymyositis.

Another possible explanation for the discrepant results may be genuine geographical differences in the aetiopathogenesis in that viruses may play a part in patients in some countries or regions, but not in others.

To summarise, with the use of a sensitive and specific PCR technique we did not detect enterovirus and EMC virus RNA in muscle agreement with other PCR studies, which did not detect viral RNA for coxsackievirus $B$, EMC virus, mumps virus, adenovirus, ${ }^{24}$ or enteroviral RNA $^{25}$ in muscle tissues from adul patients with polymyositis or dermatomyositis. 


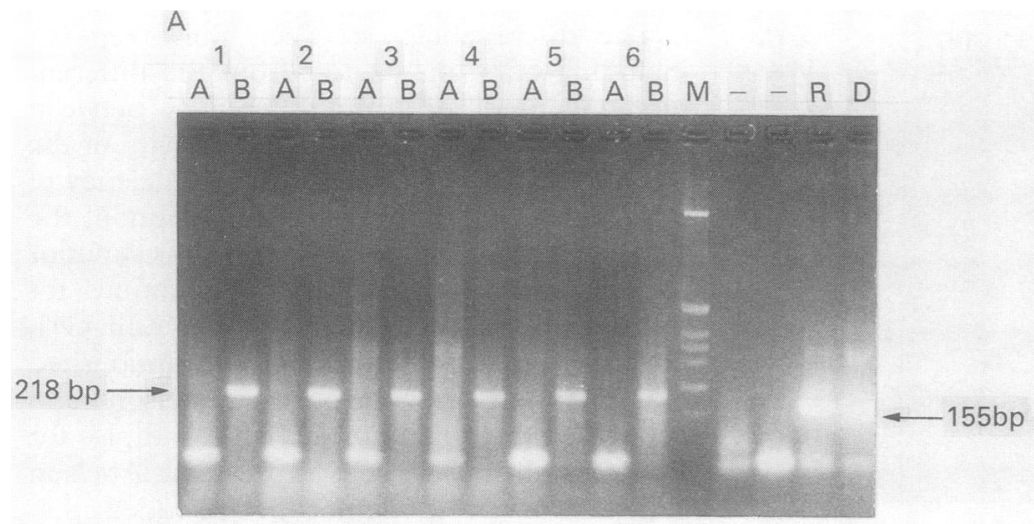

B
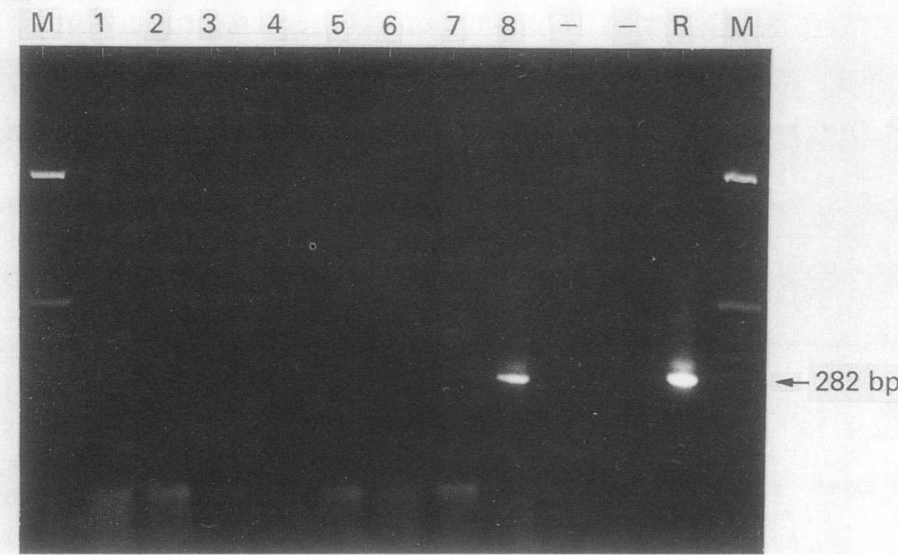

Figure 2 Gel electrophoresis showing the results of polymerase chain reaction analysis for enterovirus RNA in muscle samples from four patients with polymyositis (lanes $1 A-4 A$ ), two patients with dermatomyositis (lanes $5 A-6 A$ ), and corresponding internal controls (lanes $1 B-6 B ; m R N A$ of the Abelson tyrosine kinase gene). Lane $M$, length marker ( $p$ BR322 $\times$ HinfI);--, negative controls (distilled water); lane $R$, positive control (coxsackievirus B1 RNA); lane D, positive control (coxsackie virus B3 cDNA).

(B) Gel electrophoresis showing the results of polymerase chain reaction analysis for encephalomyocarditis (ECM) virus RNA in muscle samples from four patients with polymyositis (lanes 1-4), two patients with dermatomyositis (lanes 5-6), one muscle sample from an uninfected mouse (lane 7), and one muscle sample from a mouse inoculated with EMC (lane 8). Lane M, length marker ( $p$ BR322× HinfI); lane -, negative controls (distilled water); lane $R$, positive control (EMC RNA).

from adult patients with active polymyositis or dermatomyositis. Therefore, our data do not favour the proposal that persistent virus RNA plays a part in the maintenance of the adult onset forms of these idiopathic inflammatory myopathies. Given the discrepancies between serological, conventional hybridisation, and PCR results, studies in childhood and adult patients are needed to compare the sensitivity and specificity of various techniques in detecting viral RNA. Until such data are available, this subject is likely to remain controversial.

We thank Inge Bergmann for excellent technical assistance, Dr C W G M Frenken and M J J Prick, neurologists at the CanisiusWilhelmina Zickenhuis, Nijmegen, for referring their patients, Th Polder for taking the muscle biopsy samples, and P Jap for the use of muscle samples. This study was supported by grant from the Prinses Beatrixfonds (grant numbers 89-2999 and 90-3137)
1 Dalakas M C. Polymyositis, dermatomyositis, and inclusion-body myositis. $N$ Engl f Med 1991; 325: 1487-98.

2 Banker B, Engel A G. The polymyositis and dermatomyositis syndromes. In: Engel A G, Banker B Q, eds. Myology. New York: McGraw-Hill, 1986: 1385-423.

3 Love L A, Leff R L, Fraser D D, et al. A new approach to the classification of inflammatory myopathy: myositisspecific autoantibodies define useful homogeneous patient groups. Medicine (Baltimore) 1991; 70: 360-74.

4 Notkins A L, Onodera T, Prabhakar B S. Virus-induced autoimmunity. In: Notkins A L, Oldstone M B A, eds. Concepts in viral pathogenesis. New York: Springer, 1984: $210-5$.

5 Haspel M V, Onodera T, Prabhakar B S, Horita M, Suzuki $\mathrm{H}$, Notkins A L. Virus-induced autoimmunity: monoclonal antibodies that react with endocrine tissues. Science 1982; 220: 304-6.

6 Strongwater S L, Dorovini-Zis K, Ball R D, Schnitzer T J. A murine model of polymyositis induced by Coxsackievirus B1 (Tucson strain). Arthritis Rheum 1984; 27: $433-42$.

7 Lau J Y N, Davis G. Managing chronic hepatitis C virus infection. $B M F$ 1993; 306: 469-70

8 Gyorkey F, Cabral G A, Gyorkey P K, Uribe-Botero G, Dreesman G, Melnick J L. Coxsackievirus aggregates in muscle cells of a polymyositis patient. Intervirology 1977; 10: $69-77$.

9 Travers R L, Hughes G R V, Cambridge G, Sewell J R. Coxsackie $\mathbf{B}$ neutralisation titres in polymyositis/ dermatomyositis. Lancet 1977; i: 1268 .

10 Christensen M L Pachman L M, Schneiderman R, Patel D C, Friedman J M. Prevalence of coxsackie B virus antibodies in patients with juvenile dermatomyositis. antibodies in patients with juven
Arthritis Rheum 1986; 29: 1365-70.

11 Bowles N E, Dubowitz V, Sewry C A, Archard L C. Dermatomyositis, polymyositis, and Coxsackie-B-virus infection. Lancet 1987; i: 1004-7.

12 Bunn C C, Walport M J. Failure to detect Coxsackie virus specific sequences in muscle biopsies from polymyositis patients [abstract]. Br $\mathcal{F}$ Rheumatol 1989; 28(suppl 2): 124

13 Yousef G E, Isenberg D A, Mowbray J F. Detection of enterovirus specific RNA sequences in muscle biopsy specimens from patients with adult onset myositis. Ann Rheum Dis 1990; 49: 310-5.

14 Rosenberg N L, Rotbart H A, Abzug M J, Ringel S P, Levin $M$ J. Evidence for a novel picornavirus in human M J. Evidence for a novel picornavirus in
dermatomyositis. Amm Neurol 1989; 26: 204-9.

15 Chomczynski P, Sacchi N. Single-step method of RNA isolation by acid guanidinium thiocyanate-phenolchloroform extraction. Anal Biochem 1987; 162: 156-9.

16 Zoll G J, Melchers W J G, Kopecka H, Jambroes G, van der Poel H J A, Galama J M D. General primer mediated PCR for the detection of enteroviruses: application for diagnostic routine and persistent infections. I Clin Microbiol 1992; 30: 160-5.

17 Olive D M, Al-Mufti S, Al-Mulla W, et al. Detection and differentiation of picornaviruses in clinical samples following genomic amplification. I Gen Virol 1990; 71: 2141-7.

18 Tam P E, Schmidt A M, Ytterberg S R, Messner R P. Viral persistence during the developmental phase of persistence during the developmental phase of 1991; 65: 6654-60.

19 Cronin M E, Love L A, Miller F W, McClintock P R, Plot\% $\mathrm{P}$ H. The natural history of encephalomyocarditis virusinduced myositis and myocarditis in mice: viral persistence demonstrated by in situ hybridization. 7 Exp Med 1988; 168: 1639-48.

20 Archard L C, Bowles N E, Olsen E G J, Richardson P J. Detection of persistent coxsackie $\mathrm{B}$ virus RNA in dilated cardiomyopathy and myocarditis. Eur Heart $\mathcal{7} 1987$; 8: 437-40

21 Kandolf E, Ameis D, Kirschner P, Canu A, Hofschneider $\mathrm{P} \mathrm{H}$. In situ detection of enteroviral genomes in myocardial cells by nucleic acid hybridization: an approach to the diagnosis of viral heart disease. Proc Natl Acad Sci USA 1987; 84: 6272-6.

22 Jin O, Sole M J, Butany J W, et al. Detection of enterovirus RNA in myocardial biopsies from patients with myocarditis and cardiomyopathy using gene amplification myocarditis and cardiomyopathy using gene amplification
by polymerase chain reaction. Circulation 1990; 82: 8-16.

23 Gow J W, Behan W M H, Clements G B, Woodall C, Riding $M$, Behan P O. Enteroviral RNA sequences detected by polymerase chain reaction in muscle of patients with postviral fatigue syndrome. BMF 1991; 302: 692-6.

24 Leff R L, Love L A, Miller F W, et al. Viruses in idiopathic inflammatory myopathies: absence of candidate viral genomes in muscle. Lancet 1992; 339: 1192-5.

25 Leon-Monzon M, Dalakas $M$. Absence of persistent infection with enteroviruses in muscles of patients with inflammatory myopathies. Ann Neurol 1992; 32: 219-22.

26 Minnich L, L, Ray C G. Variable susceptibility of mice to group B Coxsackievirus infections. F Clin Microbiol 1980; 11: $73-5$. 